\title{
Relationship between Locus of Control Orientation and School Adjustment of Orphaned and Vulnerable Pupils in Kisumu Central Sub County, Kenya.
}

\author{
Linah Anyango Ochieng ${ }^{1 *}$, Manson Sichari ${ }^{2} \&$ Joel Ogutu ${ }^{2}$ \\ ${ }^{1}$ Department of Educational Psychology, Masinde Muliro University of Science and Technology, P. O. Box 190 \\ - 50100, Kakamega, Kenya. \\ ${ }^{2}$ Department of Educational Psychology, Masinde Muliro University of Science and Technology, P. O. Box 190 \\ - 50100, Kakamega, Kenya. \\ *E-mail of corresponding author: anyangolinah@gmail.com
}

\begin{abstract}
This study investigated the relationship between locus of control orientation and school adjustment of orphaned and vulnerable pupils (OVP) in primary schools in Kisumu Central Sub County, Kenya. It adopted a correlational research design. Purposive and snowball sampling techniques were used to sample 284 participants which included 248 OVP and 36 class teachers. Data was collected using an adapted form of Nowicki-Strickland locus of control scale for children (N-SLOC) and a modified form of teacher rating scale of school adjustment (TRSSA). The instruments were piloted in two schools to determine their validity and reliability. Content validity was ascertained by incorporating results of the pilot study and views of experts in the Department of Educational Psychology of Masinde Muliro University of Science and Technology. On the other hand, split-half technique corrected by Spearman-Brown formula was used to determine reliability of the data collection instruments. N-SLOC yielded a reliability coefficient of .793 while TRSSA, .995. Data was analysed using inferential statistics at .05 level of statistical significance and 95\% confidence level. Statistical package for social sciences (SPSS) version 25 aided in the analysis. Results revealed a weak significant positive correlation between locus of control orientation and school adjustment, $r=.183, d f=246, p<.05$. Recommendations were made that could help stakeholders respond to OVP in ways that increase their comfortability and ultimate adjustment in the school environment.
\end{abstract}

Key words: Adjustment, locus of control orientation, orphan, school adjustment and vulnerable pupil.

DOI: $10.7176 / \mathrm{JEP} / 11-21-16$

Publication date:July 31 st 2020

\section{Introduction}

Realization of meaningful education may be one of the main ways of equipping learners with skills necessary for future self-reliance. However, early death of parent(s) often expose pupils to stress, emotional problems and psychological trauma which interfere with their efficient adjustment in the school environment (Magampa, 2014). The term adjustment denotes a psychological process by which an individual attempts to deal with stress, tension and conflicts so as to meet his or her needs while making efforts at the same time to maintain harmonious relationships with the environment (Opara \& Onyekuru, 2013). Orphaned and vulnerable pupil (OVP) can therefore be said to experience positive school adjustment when there is a match between their competence to deal with their stressors while at the same time meeting their needs and the demands placed on them by the school environment. As a result, school adjustment is indicated differently according to varied authors. Ahmed (2017) defined it as the degree to which children are comfortable, engaged and successful in the school environment, while according to Winga, Agak \& Ayere (2011), the concept of school adjustment also includes academic achievement, school satisfaction and pro social behaviour. Furthermore, Jaureguizar, Beraras, Soroa, Sarasa \& Garaigorbil (2015) conceptualize school adjustment to reflect extent to which pupils are interested, engaged and successful at school. Similarly, it takes into account academic achievement, personal growth and accomplishment outside the classroom, and is emphasized through analysing pupil's school efficiency, progress, success, ability to create relationships with the teachers and other pupils, and to internalize school rules and accepted social values (Adeusi, Adekeye \& Babalola, 2015; Emilia, 2016). In the present study, school adjustment is indicated by ontask classroom involvement, social competence and positive orientation as demonstrated by OVP in the school environment. On-task classroom involvement is envisaged as the extent to which OVP appropriately engaged in classroom tasks from time to time while social competence refers to OVP's ability to positively relate with and accept association with peers and teachers as a way of enhancing their interactions within the school environment. Positive orientation on the other hand refers to the extent to which OVP approach school tasks and teachers with a positive attitude and enthusiasm. 
Toheed (2012) posits that a child's adjustment to school is ultimately determined by the interaction between the pupils' personal characteristics and their experiences. One such personal characteristics is locus of control orientation. The concept of locus of control was introduced by Julian Rotter in 1954 to help explain people's traits and behaviours (Health Psychology, 2012; Choudhury \& Borooah, 2017). Cobb-Clark (2014) described locus of control as a generalized attitude, belief, or expectancy regarding the nature of the causal relationship between one's own behaviour and its consequences. Locus of control therefore denotes extent to which individuals perceive an internal or external control of events in their lives. Individuals who perceive control of their life events as lying within them are described as demonstrating internal locus of control while those who perceive events in their lives as being influenced by forces external to them are described as demonstrating external locus of control. The term locus of control orientation therefore refers to a person's inclination to believe that outcome of events in their lives is determined by forces that are either internal or external to them. Consequently, individuals with internal locus of control orientation acknowledge that the responsibility to get the rewards they seek result from their own actions or is ultimately determined by factors within them for instance their hard work, decision-making, skills, effort and persuasion (Hill, 2016; Mearns, 2018) while those who have external locus of control orientation believe that the outcome of their behaviours depend on luck, fate, coincidence, other people, task difficulty, or chance (Hill, 2016; Choudhury \& Borooah, 2017). Thus, whether OVP attribute outcome of their life events to an internal or external cause may be one of the expectancy styles which determines their motivation to behave and respond to their problematic situations in ways which eventually influence their adjustment to school. However, little is known on how OVP's personality characteristics, specifically locus of control orientation, relates with their school adjustment. Consequently, a greater understanding of the relationship between locus of control orientation and school adjustment of orphaned and vulnerable pupils in primary schools in Kisumu Central Sub County, Kenya is necessary.

Furthermore, whereas according to United Nations Children's Fund (UNICEF) (2017), an orphan is a child less than 18 years of age who has lost one or both parents to any cause of death, in this study, the term orphan refers to a pupil aged between 10 and 12 years whose one of the parents or both parents have died. Additionally, according to Joint United Nations Programme in HIV and AIDS (UNAIDS) Inter Agency Task Team on Education (2004, p.13), vulnerable children are "children whose safety, well-being and development are for various reasons threatened... particularly because they do not have the emotional and physical maturity to adequately address and bear the psychological trauma associated with parental loss". In this study, a vulnerable pupil refers to a male or female pupil aged between 10 and 12 years whose one or both parents have died and is receiving care in an orphanage, from an organization, or from any other person other than a biological parent.

Orphaned students perform poorly in school (Oyedele, Chikwature \& Manyange, 2016). They are also known to experience stress, emotional problems, and physical as well as psychological trauma (Magampa, 2014). Report by Kiambi \& Mugambi (2017) that survival rate of OVP in Kenya from class one to eight was below 40\%, while that of those moving from class one to university was $1.69 \%$ further emphasized negative influence of orphanhood on OVP's school success. This was underscored by findings by Owaa, Aloka \& Raburu (2015) which revealed that emotional progression factors affected adjustment of orphaned secondary school students to loss and grief. That study also reported that Kenya Institute of Professional Counsellors traced $63 \%$ of cases of truancy they handled to orphans, and that $56 \%$ of orphans who requested for therapy in Kisumu Central Sub County discussed their loss. Reports from Kisumu Central Sub County children's office obtained through researcher's personal interaction with that office in early 2018 further showed that most orphans receiving care and protection in various children's homes in the Sub County were doing poorly in school, suffered low self-esteem and tended to be psychologically disturbed. This scenario showed that OVP have not been able, or assisted adequately, to deal with the challenges orphanhood impose on their path toward school success. Yet the Ministry of Education Science and Technology (MOEST) (2014) put the number of OVP in primary schools in Kisumu County at 67008 of whom 12831 were in schools in urban and semi-urban areas of the County. Kisumu Central Sub County being the hub of Kisumu County could therefore be home to a substantial number of OVP in primary schools.

The purpose of this study was to establish the relationship between locus of control orientation and school adjustment of OVP in primary schools in Kisumu Central Sub County, Kenya, while the objective was to determine the correlation between locus of control orientation and school adjustment of OVP in primary schools in Kisumu Central Sub County, Kenya. It was hoped that this study might generate new knowledge on how OVP's personality characteristic of locus of control orientation relates with their school adjustment in order to help stakeholders devise effective mitigation strategies to increase school success of OVP. The study was conducted in Kisumu Central Sub County, Kenya. Participants included OVP in primary schools and their class teachers. 


\section{Review of related literature}

Webber, Krylow \& Zhang (2013) examined indicators of college student success and satisfaction in USA to establish whether involvement really mattered. The study established that higher levels of involvement in a variety of curricular and co-curricular activities significantly contributed to cumulative GPA and students' perception of the overall academic experience. However, that study lacked a measure to determine students' motivation to become involved in various academic activities. In another study, Sarwar \& Ashrafi (2014) analysed commitment, engagement and locus of control as predictors of academic achievement at higher level of education. The study found significant positive impact of commitment, engagement and locus of control on academic achievement. However, in that study, commitment, engagement and locus of control were all independent variables while in the present study, locus of control orientation was the independent variable. Hence as much as a statistically significant positive impact of locus of control alongside other variables on academic achievement was found, the link between locus of control orientation and on-task classroom involvement still remained unclear.

In addition, Ndiewo, Aloka \& Raburu (2016) investigated the influence of learners' involvement on academic performance of secondary school students in Bondo Sub County, Kenya. Findings revealed existence of a statistically significant relationship between learner involvement and academic performance. Although this study yielded results that were consistent with earlier findings by Webber, et al. (2013) Sarwar \& Ashrafi (2014), not much was known on how learners' involvement associated with locus of control orientation of OVP in primary schools in Kisumu Central Sub County, Kenya. Furthermore, Wara, Aloka \& Odongo (2018) investigated the relationship between student cognitive engagement and academic achievement of secondary school in Nyamira County, Kenya. Results revealed that cognitive engagement was a significant predictor of academic achievement. However, this study did not focus on locus of control orientation besides involving secondary school students who were also not necessarily orphaned. As a result a need remained to find out the connection between locus of control orientation and on-task classroom involvement of OVP in primary schools in Kisumu Central Sub County, Kenya.

In another study, Hui, Prihadi, Arif, Yap, Chua, Chen, Chong \& Yeow (2019) carried out a research to find out whether classroom engagement mediated the relationship between students' internal locus of control and academic procrastination. Findings revealed that internal locus of control had a significant positive effect on classroom engagement. This finding is similar to Laat (2016) whose study found a direct effect of internal locus of control on work engagement. However, it did not explain the relationship between locus of control orientation and on-task classroom involvement as an element of school adjustment of OVP. That is the gap the present study sought to fill.

Satici, Uysal \& Akin (2013) examined the relationships between social support and academic locus of control. Results showed that internal academic locus of control was predicted positively by dimensions of social support. However, the study was done in Turkey while the present study was done in Kenya, and the subjects were mainstream university students while in the current study subjects were OVP in primary schools. Furthermore, it explored the relationships between social support and academic locus of control therefore the relationship between locus of control orientation and social competence as an element of school adjustment of OVP in primary schools in Kisumu Central Sub County Kenya still remained unknown. The current study filled that gap.

Bahrainian \& Yari (2014) also conducted a correlational study to investigate the relationship between locus of control and social support with social adjustment in accounting Trainees in Iran. Results showed a statistically significant positive correlation between locus of control and social adjustment. However, that study focused on social adjustment as opposed to social competence as in the current study. Ghartappeh, Talepasand, Manshaee, Abolfathi, Solhi \& Gharatappeh (2015) also carried out a descriptive cross-sectional study on the relationship between personal and social adjustment with locus of control and gender in intelligent high school students in Iran. The study revealed that locus of control was a related factor on social adjustment in the intelligent high school students. Though these findings are consistent with those of studies by Satici et al, (2013) and Bahrainian \& Yari (2014), the reviewed study focused on intelligent high school students in Iran while the current study focused on OVP in primary schools in Kenya. In addition, besides using Rotter's locus of control scale, part of the California psychological inventory had items which addressed social adjustment and not social competence hence these instruments did not yield data that clearly showed the kind of relationship which existed between locus of control orientation and social competence particularly of the special population, OVP, in Kenya.

Langat (2015) conducted a descriptive survey on students' attitudes and their effects on learning and achievement in Mathematics in Kiambu, Kenya. The study found that most students had a positive attitude towards mathematics though this did not translate to good grades. Participants in this study were form fours and it emphasized effects of student's attitude on achievement in Mathematics, a compulsory subject, hence it was not clear how objectively 
the subjects responded to items in the questionnaire. Besides, relationship between locus of control orientation and positive orientation as an element of school adjustment still remained unknown. That is the gap this study sought to fill.

Senler (2016) on the other hand examined a conceptual model of the relationships between pre-service science teachers' teaching self-efficacy, locus of control, attitude towards science teaching and teaching anxiety in Turkey. The study established a statistically significant positive relationship between pre-service science teachers' locus of control and attitude towards science teaching. Participants in the reviewed study were teacher trainees in their last year of study, hence they could have developed a favourable disposition towards teaching science, while those in the current study were OVP in primary school. It therefore failed to shed light on the relationship between locus of control orientation and positive orientation of OVP in primary schools in Kisumu Central Sub County, Kenya. The present study filled this knowledge gap.

Additionally, Atibuni et al. (2017) conducted a quantitative study using cross-sectional survey design on locus of control as a predictor of academic attitudes among university students in Uganda. Results showed that locus of control significantly predicted academic attitudes. However, the study did not shed light on positive orientation which in the present study included positive attitude and enthusiasm with which OVP approached school tasks and teachers. It therefore remained necessary to find out the association between locus of control orientation and positive orientation of OVP in Kisumu Central Sub County, Kenya. In another study, Celik \& Saricam (2018) examined the possible relationships between academic locus of control, positive thinking skills and grit in high school students in Turkey. Results revealed existence of a significant positive correlation between internal academic locus of control and positive thinking skills, and a significant positive correlation between internal academic locus of control and grit. These findings appeared consistent with those of Senler (2016) and (Atibuni et al., 2017). However, the relationship between locus of control orientation and positive orientation of OVP in primary schools in Kisumu Central Sub County, Kenya remained unknown. The current study filled this gap.

\section{Research Methodology \\ 3.1 Research Design}

This study adopted correlational research design to enable establish existence or non-existence of a relationship between the locus of control orientation and school adjustment (Kombo \& Tromp, 2006). The approach helped indicate whether and to what degree a relationship existed between locus of control orientation and school adjustment of OVP in primary schools in Kisumu Central Sub County, Kenya.

\subsection{Area of Study}

The study was carried out in Kisumu Central Sub County which is one of the seven sub counties of Kisumu County in Western Kenya. The Sub County is basically located within Kisumu City, the third largest city in Kenya, at latitude is $0^{0} 6^{\prime} 0^{\prime \prime} \mathrm{S}$ and longitude $34^{\circ} 45^{\prime} 0^{\prime \prime} \mathrm{E}$. Consequently, its inhabitants are diverse in terms of race and ethnicity though Africans and Luos dominate. Poverty is an issue of concern particularly among the natives and those living in slum areas. Besides, predominant economic activities include small scale fishing along the shores of Lake Victoria, transportation services, mainly human transport, and trade. Several children's homes and orphanages existed in the Sub County but only eight were registered with the sub county children's office. Of the eight, two were government institutions one of which is a juvenile remand home so the children were not attending school. Most OVP were learning in the public primary schools in the slums and periphery of the city as schools in the CBD were deemed expensive by majority of care givers. Kisumu Central Sub County was selected as the study locale because it has a large number of OVP whose school success may be threatened hence the need to identify and put in place appropriate mitigation measures.

\subsection{Sampling Procedure}

Participants in the study were selected using purposive and snowball sampling techniques. Purposive sampling is a non-probability sampling method that involves deliberate selection of particular units of the study population to constitute a sample which represents the universe (Kothari \& Garg, 2019). For the purpose of this study, 36 class teachers were hand-picked for inclusion in the study. The class teachers were identified as best respondents for teacher rating scale of school adjustment because they viewed a wide range of pupils' classroom behaviours that the researcher was not able to observe during the data collection process (Betts \& Rotenberg, 2007). They were also thought to be able to respond to the items more objectively than the OVP thus minimizing bias in resultant data. Besides, snowball sampling, also non-probability sampling technique, was used to identify 8 (eight) schools and $248 \mathrm{OVP}$ aged between 10 and 12 years for inclusion in the study. The researcher was referred to the schools by the orphanages and organizations which supported orphans and vulnerable children. In the schools, the researcher was referred to Heads of Guidance and Counselling department. They collaborated with class teachers 
to assist identify OVP, while some OVP were identified by their colleagues. Thus, this technique was used because OVP were difficult to identify and contact, and were only located through referral networks (Cooper \& Schindler, 2014). These children, according to Berk (2013), were at a formative stage in line with Erik Erikson's psychosocial stage of industry versus inferiority which occurs between ages 6-12 years. At this stage the youngsters learn to work and cooperate with others (industry), or their negative experiences at home, school, or with peers foster feelings of incompetence (inferiority). It was therefore important to study the relationship between OVP's locus of control orientation and their school adjustment at this stage so that any maladaptive functioning was corrected on time.

\subsection{Data collection tools}

Data was collected using Nowicki-Strickland Locus of Control Scale for Children and Teacher Rating Scale of School Adjustment (Betts \& Rotenberg, 2007; Nowicki, 2017). The N-S LOC was adapted and used to collect data on locus of control orientation of sampled OVP. Orphaned and venerable pupils completed 12-items questionnaires by ticking AGREE or DISAGREE column against each item. Restricting responses to AGREE or DISAREE helped capture participants' subjective perception of the location of their reinforcement in a more unequivocal manner. Scoring was done in the internal locus of control orientation direction hence each 'correct answer' scored 2 (two), while items answered towards external locus of control orientation direction scored 1 (one). Additionally, OVP's school adjustment was determined using a modified form of the TRSSA. This study adapted a 14-items version of the scale to make it more relevant in the Kenyan context. Class teachers responded to it on a five-point Likert scale to assess adjustment behaviour of OVP in school on three subscales namely ontask classroom involvement, social competence and positive orientation. Level of school adjustment was determined by summing up scores under each sub section.

\subsection{Data Analysis}

Data analysis involved inferential statistics at .05 level of statistical significance and $95 \%$ confidence level. It was done with the help of SPSS version 25. Pearson correlation coefficient $r$ was computed to test the null hypothesis, $H_{0}$, which stated "there is no statistically significant correlation between locus of control orientation and school adjustment of OVP in primary schools in Kisumu Central Sub County, Kenya". However, since school adjustment was conceptualized as on-task classroom involvement, social competence, and positive orientation, three supplementary hypotheses were developed for testing. The supplementary hypotheses were as follows;

$H_{O 1.1}$ There is no statistically significant correlation between locus of control orientation and on-task classroom involvement of OVP in primary schools in Kisumu Central Sub County, Kenya.

$H_{O 1.2}$ There is no statistically significant correlation between locus of control orientation and social competence of OVP in primary schools in Kisumu Central Sub County, Kenya.

$H_{O 1.3}$ There is no statistically significant correlation between locus of control orientation and positive orientation of OVP in primary schools in Kisumu Central Sub County, Kenya.

\section{Results and Discussions}

\subsection{Correlation between locus of control orientation and on-task classroom involvement of OVP}

Pearson $r$ correlation was computed to determine the correlation between locus of control orientation and on-task classroom involvement of OVP in primary schools in Kisumu Central Sub County, Kenya. The results are presented in Table 1

\section{Table 1: Correlation between locus of control orientation and on-task classroom involvement of OVP}

\begin{tabular}{cccc}
\hline & & & $\begin{array}{c}\text { On-task } \\
\text { Classroom } \\
\text { Involvement } \\
\text { scores }\end{array}$ \\
\hline OVPs' locus of control & Pearson Correlation & $\begin{array}{c}\text { OVPs' locus of } \\
\text { control scores }\end{array}$ & $\begin{array}{c}.201^{* *} \\
\text { scores }\end{array}$ \\
& Sig. (2-tailed) & 1 & .001 \\
& $\mathrm{~N}$ & 248 & 248 \\
\hline
\end{tabular}

**. Correlation is significant at the 0.01 level (2-tailed).

From Table 1, results of pearson $(r)$ revealed a weak significant positive correlation between locus of control orientation and on-task classroom involvement, $r=.201, \mathrm{df}=246, \mathrm{p}<.05$. The first supplementary null hypothesis $\left(H_{O 1.1}\right)$ was therefore rejected. Overall, the results showed that there was a weak positive correlation between locus of control orientation and on-task classroom involvement of OVP. This suggests that increase in locus of control 
orientation was associated with a small increase in on-task classroom involvement of OVP in primary schools in Kisumu Central Sub County, Kenya. These results are corroborated by findings by Hui et al. (2019) which revealed that internal locus of control had a significant positive effect on classroom engagement, and that of a by Laat (2016) which found that individuals with internal locus of control were more work engaged. However, they differed from earlier findings which found no statistically significant association between locus of control and academic functioning (Hill, 2016).

\subsection{Correlation between locus of control orientation and social competence of OVP}

Pearson $r$ correlation was likewise computed to determine the correlation between locus of control orientation and social competence of OVP in primary schools in Kisumu Central Sub County, Kenya. The results are presented in Table 2.

Table 2: Correlation between locus of control orientation and social competence of OVP

\begin{tabular}{|c|c|c|c|}
\hline & & $\begin{array}{l}\text { OVPs' locus of } \\
\text { control scores }\end{array}$ & $\begin{array}{l}\text { Social } \\
\text { competence } \\
\text { scores }\end{array}$ \\
\hline \multirow{3}{*}{$\begin{array}{l}\text { OVPs' locus of control } \\
\text { scores }\end{array}$} & Pearson Correlation & 1 & $.182^{* *}$ \\
\hline & Sig. (2-tailed) & & .004 \\
\hline & $\mathrm{N}$ & 248 & 248 \\
\hline
\end{tabular}

**. Correlation is significant at the 0.01 level (2-tailed).

From Table 2, results of pearson $(r)$ revealed a weak significant positive correlation between the two variables, $r$ $=.182, \mathrm{df}=246, \mathrm{p}<.05$. The second supplementary null hypothesis $\left(H_{O 1.2}\right)$ was therefore rejected. Overall, the results showed that there was a weak positive correlation between locus of control orientation and social competence of OVP. This suggests that increase in locus of control orientation was associated with a small increase in social competence of OVP in primary schools in Kisumu Central Sub County, Kenya. These findings agreed with those of Bahrainian \& Yari (2014) whose research revealed a statistically significant positive correlation between locus of control and social adjustment among accounting Trainees in Iran, and Ghartappeh et al. (2015) whose study showed that locus of control was a related factor on social adjustment among the intelligent high school students in Iran.

\subsection{Correlation between locus of control orientation and positive orientation of OVP}

Pearson $r$ correlation was once more computed to determine the correlation between locus of control orientation and positive orientation of OVP in primary schools in Kisumu Central Sub County, Kenya. The results are presented on Table 3 .

Table 3: Correlation between locus of control orientation and positive orientation of OVP

\begin{tabular}{cccc}
\hline & & $\begin{array}{c}\text { OVPs' locus of } \\
\text { control scores }\end{array}$ & $\begin{array}{c}\text { Positive } \\
\text { orientation } \\
\text { scores }\end{array}$ \\
\hline OVPs' locus of control & Pearson Correlation & 1 & .110 \\
scores & Sig. (2-tailed) & & .085 \\
& $\mathrm{~N}$ & 248 & 248 \\
\hline
\end{tabular}

From Table 3, results of pearson ( $r$ ) revealed no statistically significant correlation between the two variables, $r$ $=.110, d f=246, p>.05$. The third supplementary null hypothesis $\left(H_{O 1.3}\right)$ was therefore retained. Overall, the results from Table 3 revealed no statistically significant correlation between locus of control orientation and positive orientation of OVP. This suggests that increase in locus of control orientation was associated only with a chance increase in positive orientation of OVP in primary schools in Kisumu Central Sub County, Kenya. This finding differed from those of studies by Atibuni et al, (2017) which revealed that locus of control predicted 3.2\% of the students' academic attitudes, Senler (2016) who found a statistically significant positive relationship between pre-service science teachers' locus of control and attitude towards science teaching, and Langat (2015) 
whose study found that most students had a positive attitude towards mathematics though that did not translate to good grades.

Overall pearson $r$ correlation was computed to test the null hypothesis, $H_{0}$, which stated "there is no statistically significant correlation between locus of control orientation and school adjustment of OVP in primary schools in Kisumu Central Sub County, Kenya." Results are presented in Table 4.

Table 4: Overall correlation between locus of control orientation and school adjustment of OVP

\begin{tabular}{|c|c|c|c|}
\hline & & $\begin{array}{l}\text { OVPs' locus of } \\
\text { control scores }\end{array}$ & $\begin{array}{l}\text { OVPs' overall } \\
\text { school } \\
\text { adjustment } \\
\text { scores } \\
\end{array}$ \\
\hline \multirow{3}{*}{$\begin{array}{l}\text { OVPs' locus of control } \\
\text { scores }\end{array}$} & Pearson Correlation & 1 & $.183^{* *}$ \\
\hline & Sig. (2-tailed) & & .004 \\
\hline & $\mathrm{N}$ & 248 & 248 \\
\hline
\end{tabular}

**. Correlation is significant at the 0.01 level (2-tailed).

From Table 4, results of pearson $(r)$ revealed a weak significant positive correlation between locus of control orientation and school adjustment, $r=.183, d f=246, p<.05$. Thus the null hypothesis $\left(H_{0}\right)$ was rejected. Overall, the result showed a weak positive correlation between locus of control orientation and school adjustment of OVP. This suggested that an increase in locus of control orientation was associated with a small increase in the level of school adjustment of OVP in primary schools in Kisumu Central Sub County, Kenya.

\section{Conclusions and Recommendations}

The purpose of the study was to establish the relationship between locus of control orientation and school adjustment of orphaned and vulnerable pupils in primary schools in Kisumu Central Sub County, Kenya. The study found a weak statistically significant positive correlation between locus of control orientation and school adjustment of OVP. Hence, an increase in locus of control orientation was associated with a small increase in the level of school adjustment of OVP in primary schools in Kisumu Central Sub County, Kenya. These findings showed that OVP's personality characteristic of locus of control orientation correlated with their school adjustment only to a limited extent. The researcher therefore recommends that stakeholders in the field of education in Kenya should strengthen other factors external to OVP for instance school counselling, teachers-OVP relationship and care of OVP to increase OVP's comfortability and ultimate adjustment in the school environment.

\section{References}

Adeusi, S., Adekeye, O. \& Babalola, O. (2015). Influence of guidance and counselling on students' motivation and school adjustment among Covenant University, Ogun state. Proceedings of Edulearn 15 Conference, 4400 - 4406, Spain.

Ahmed, S. (2017). Shyness and school adjustment: Moderating role of teacher-child relationships. Unpublished Master's Thesis, University of Oslo.

Atibuni, D. Z., Ssenyonga, J., Olema, D. K. \& Kemeza, I. (2017). Locus of control as predictor of academic attitudes among university students. International Journal of Educational Policy Research and Review, 4 (6), 125-137.

Bahrainian, A. \& Yari, M. (2014). The relationship between locus of control and social support with social adjustment in vocational school's trainees in Tehran. Journal of Applied Environmental and Biological Sciences, 4(4), 271-277.

Berk, L. A. (2013). Child development. ( $9^{\text {th }}$ ed). New Jersey: Pearson Education.

Betts, L. R. \& Rotenberg, K. J. (2007). A short form of teacher rating scale of school adjustment. Journal of Psychoeducational Assessment, 25(2), 150-164.

Celik, I. \& Saricam, H. (2018). The relationships between positive thinking skills, academic locus of control and grit in adolescents. Universal Journal of Educational Research, 6(3), 392-398.

Choudhury, S. A. Borooah, I. P (2017). Locus of control and academic achievement of undergraduate college students of Guwahati City. International Journal of Humanities and Social Science Invention, 6 (4), 67-70.

Cobb-Clark, D. (2014). Locus of control and labour market. IZA Discussion Paper No.8678. Melbourne Institute, University of Melbourne and Life Course Centre, Germany.

Cooper, D. R. \& Schindler, P. S. (2014). Business research methods. (12 ${ }^{\text {th }}$ ed.). New York: McGraw Hill.

Emilia, C. (2016). Students' school adjustment / maladjustment through preparatory class. Education, Reflection, Development. $\left(4^{\text {th }} \mathrm{ed}\right)$. The European proceedings of social behavioural sciences, 109-122.

Ghartappeh, A., Talepasand, S., Manshaee, G. R., Abolfathi, M., Solhi, M., \& Gharatappeh, S. (2015). Relationship between personal and social adjustment with locus of control and gender in intelligent high school student. Iranian Journal of Health Education and Health Promotion, 3 (2), 159-165.

Health Psychology (2012). The concept of locus of control. Psychology notes headquarters. Retrieved from https:/www.psychologynoteshq.com/locusof control/ 
Hill, R. (2016). Locus of control, academic achievement and discipline referrals. Murray State Theses and Dissertations

Hui, Y. L, Prihadi, K., Arif, N. I., Yap, S.X.Y., Chua, M.J., Chen, J., Chong, J.C.\& Yeow, J.Y.L. (2019). In everlasting fight against academic procrastination: The roles of classroom engagement and internal locus of control. International Journal of Evaluation and Research in Education, 8(4), 647-653.

Joint United Nations Programme on HIV and AIDS Inter Agency Task Team on Education (2004). HIV / AIDS and education: The role of education in the protection, care and support of orphans and vulnerable children living in a world with HIV and AIDS: IATTOVC/RI REV.

Juareguizar, M., Bernaras, E., Soroa, M., Sarasa, M. \& Garaigordobil, M. (2015). School maladjustment in children and adolescents. Proceedings of INTED Conference, Spain.

Kiambi, G. E. \& Mugambi, M. M. (2017). Factors influencing performance of orphans and vulnerable children projects in Imenti north sub county, Meru County, Kenya. International Academic Journal of Information Sciences and Project Management, 2(1), 179-196.

Kombo, D. K. \& Tromp, D. L. (2006). Proposal and thesis writing: An introduction. Nairobi: Pauline Publications Africa.

Kothari, C. R. \& Garg, G. (2019). Research methodology: Methods and techniques. (4 $\left.{ }^{\text {th }} \mathrm{ed}\right)$. Nairobi: New Age International.

Laat, F. (2016). The effect of work locus of control on the relationship between inclusive leadership and work engagement. Unpublished Master's Thesis, Tilburg University.

Langat, A. C. (2015). Students' attitudes and their effects on learning and achievement in mathematics: a case study of public secondary schools in Kiambu County, Kenya. Unpublished Master's Thesis, Kenyatta University, Kenya.

Magampa, A. B. M. (2014). The academic performance of orphaned primary school learners aged between eight and ten years in Mankweng circuit: Limpopo province. Unpublished Master's Thesis, University of Limpopo.

Mearns, J. (2018). The social learning theory of Julian Rotter (1916-2014). Retrieved from psych.fullerton.edu/jmearns/rotter.htm

MOEST (2014). Basic education statistical booklet. Ministry of Education Science and Technology.

Ndiewo, P. O., Aloka, P. J. O. \& Raburu, P. (2016). Influence of learner involvement on academic performance of secondary school students in Kenya. International Journal of Applied Psychology, 6(2), 37-40.

Nowicki, S. J. (2017). A locus of control scale for children. Journal of Consulting and Clinical Psychology, 40(1), 148-154.

Opara, I. M. \& Onyekuru, B. U. D. (2013). Psychosocial predictors of secondary school student's adjustment to school. European Scientific Journal, 9 (17), 303-311.

Owaa, J. A., Aloka, P. J. O. \& Raburu, P. (2015). The influence of emotional progression factors on adjustment to loss and grief on Kenya orphaned secondary school students. Mediterranean Journal of Sciences, 6(4S3), 190-200.

Oyedele, V., Chikwature, M., \& Manyange, P. (2016). Challenges facing orphaned students and the effects on academic performance in o- level commerce at samaringa cluster secondary schools. International Journal of Academic Research and Reflection, 4 (3), 37.

Sarwar, M. \& Ashrafi, G. M. (2014). Students' commitment, engagement and locus of control as predictors of academic achievement at high educational level. Current Issues in Education, 17(3), 1-8.

Satici, S. A., Uysal, R. \& Akin, A. (2013). Perceived social support as predictor of academic locus of control. Education Science and Psychology, 1(23), 79-86.

Senler, B. (2016). Pre-service science teachers' self-efficacy: The role of attitude, anxiety and locus of control. Australian Journal of Education. 60(1), 26-41.

Toheed, L. (2012). Education: Education awareness and research. Retrieved from Research-educationedublogspot.co.ke/2012/04/adjustment.html?m=1

United Nations Children's Fund (2017). An orphan. Retrieved from https://www.unicef.org/media/media_45279.html

Wara, E., Aloka, P. J. O. \& Odongo, B. C. (2018). Relationship between cognitive engagement and academic achievement among Kenyan secondary school students. Mediterranean Journal of Social Sciences, 9 (2), 61-72.

Webber, K. L., Krylow R. B. \& Zhang Q. (2013). Does involvement really matter? Indicators of College Student Success and Satisfaction. Journal of College Student Development, 54(6), 591-611.

Winga, M. A., Agak, J. O., \& Ayere, A. M. (2011). The relationship among school adjustment, gender and academic achievement amongst secondary school students in Kisumu District, Kenya. Journal of Emerging Trends in Educational Research and Policy Studies, 2(6), 493-597. 